\title{
Teaching being human in global comparison
}

\author{
Hopkins, Dwight \\ University of Chicago, United States of America \\ dhopkins@uchicago.edu
}

\begin{abstract}
The current essay draws upon the author's involvement and teaching experiences within a global network of international youth-student exchanges. The central question that is brought to the fore is: How does an educator teach the idea of being human among different nations situated in the same classroom? It therefore is polarized on the question of theological anthropology, and how these notions are received within crosscultural exposure. The essay begins with the concept of culture itself, and particularly the way in which it is transmitted contemporaneously through resurfacing and enactment. The essay then moves onto the content of pedagogy, which is summarized under the themes of (1) conversation, (2) questioning, and (3) opening up traditions to new perspectives. The purpose of (1) is to emphasize and bring to the surface those crucial traditions relative to the class subject matter, while (2) seeks to teach students to not accept anything as given; to challenge students to defend the fundamentals and presuppositions of their arguments; to remind both questioner/challenger and responder/defender to always make clear the local cultural context of the challenge and the defense. And finally, (3) facilitates a moment of encounter whereby a student who is foreign is invited into another student's reality, and to see something new in an ancient memory that is different to their own. The essay closes with a suggestion that certain cultural or artistic artifacts, namely language and music, might provide a salient point for class-room discussion, especially in the way these cultural productions are received both locally and globally.
\end{abstract}

\section{Keywords}

Pedagogy; globalization; intercultural-religious dialogue; theological anthropology

For one year, I taught theology to graduate and undergraduate students in Seoul, Korea. In addition to my Black Theology: $1^{\text {st }}$ Generation; Black Theology: $2^{\text {nd }}$ Generation; and Theology and Cultural Studies classes, perhaps the most globally comparative teaching challenge took place in my 
Being Human course. The students came from Korea, Ghana, Thailand, Pakistan, China, and the USA. After a long semester of my lectures and classroom conversations, I posed to the students a simple question. In your home context, what does it mean to be human? The Korean students mentioned "food"; the Thai students indicated knowing which of the three hand positions one uses when greeting another person; the Chinese student pointed to "family"; the Ghanaian student embraced "the ancestors"; the Pakistani student asserted "no daily violence"; and the two students from the United States (both black Americans) affirmed "individual rights." During this same period, I was one of the initiators and an international coordinator of a fourteen-country network (defined by South Africa, Botswana, Zimbabwe, Ghana, Hawaii, Fiji, Japan, Australia, India, England, Cuba, Brazil, Jamaica, and the United States). The network identified the creation of new knowledge by way of transnational pedagogy as one of its stated goals. ${ }^{1}$

\section{Presuppositions to pedagogy}

These two exciting undertakings of intellectual engagement raise the question: How does an educator teach the idea of being human among different nations situated in the same classroom? ${ }^{2}$ My teaching fluidity (i.e., my teaching adaptability) presupposes that (1) all knowledge first arises

1 This eight-year global network engaged in international youth-student exchanges and women's advocacy. It published one book: Dwight N. Hopkins (USA) and Marjorie Lewis (Jamaica), co-editors, Another World Is Possible: Spiritualities and Religions of Global Darker Peoples, in the Cross Cultural Theologies Series of Equinox Publishing (London, England, 2009). Because white Christians from the mainland United States of America participated in the violent colonizing of the sovereign nation Kingdom of Hawaii in January 1893, by international law a colonized nation is still a nation, akin to how Iraq was occupied and initially colonized by the United States in 2003 and then, subsequently, resumed its sovereign nation status. See Ward Churchill and Sharon H. Venne, ed. Islands in Captivity: The International Tribunal on the Rights of Indigenous Hawaiians (Cambridge, Mass.: South End Press, 2004) and the documentary film "Act of War: The Overthrow of the Hawaiian Nation."

2 My pedagogical paradigm is partially informed by Anthony G. Reddie's Nobodies to Somebodies: A Practical Theology for Education and Liberation (London: Epworth Press, 2003), Dramatizing Theologies (Sheffield, England: Equinox Publishing, 2006), Working Against The Grain: Black Theology in the 21st Century (Sheffield, England: Equinox Publishing, 2008), "Teaching for Racial Justice: A Participative Approach", in Teaching and Learning Religion, Vol. 13, Issue No. 2, April 2012, and Black Theology (London: SCM Press, 2012); bell hooks' Teaching to Transgress: Education as the Practice of Freedom (New York: Routledge, 1994); Noel L. Erskine, Black Theology and Pedagogy 
from specific cultures, (2) human communities in those cultures define the theological anthropology, and (3) consequently, theological anthropology (i.e., the human being and its final good or the divine-human connection) lacks a universal essence or global applicability from the top down. ${ }^{3}$ Such a valuing of particularity, respect for local cultures, and accenting the human role in theological anthropology nurtures a universal spirituality of invitation, graciousness, humility, and listening in the classroom setting. When it comes to global experiences of the transcendent and human relationships found among students in the classroom, all stand on equal ground. So, the professor engenders a double encouragement. Each student recognizes the fact and truth of his/her own being human or theological anthropology from his/her home country, and each student recognizes the surface validity of other foreign students' claims to authentic human being. It is a way of teaching where different selves in conversation with many foreign neighbours bring to the market of idea exchanges the fruit of their own cultures.

(New York: Palgrave Macmillan, 2008); and Paulo Freire's Pedagogy of the Oppressed, 30th Anniversary Edition (New York: Continuum, 2000).

3 Some possible helpful texts on presuppositions to theological anthropology are: BoMyung Seo, A Critique of Western Theological Anthropology: Understanding Human Beings in a Third World Context (Lampeter, England: The Edwin Mellen Press, 2005); Andrew Sung Park, The Wounded Heart of God: The Asian Concept of Han and the Christian Doctrine of Sin (Nashville: Abingdon Press, 1993); Eleazar S. Fernandez, Reimagining the Human: Theological Anthropology in Response to Systemic Evil (St. Louis, MO: Chalice Press, 2004); George E. Tinker, Spirit and Resistance: Political Theology and American Indian Liberation (Minneapolis, MN: Fortress, 2004); Mercy Amba Oduyoye, Hearing and Knowing: Theological Reflections on Christianity in Africa (Maryknoll, N.Y.: Orbis Books, 1986); Nyambural J. Njoroge, An African Christian Feminist Ethic of Resistance and Transformation (Legon, Ghana: Legon Theological Studies, 2000); Karen Baker-Fletcher, Sisters of Dust, Sisters of Spirit: Womanist Wordings on God and Creation (Minneapolis, MN: Fortress, 2008); Phillis Isabella Sheppard, Self, Culture, and Others in Womanist Practical Theology (New York: Palgrave Macmillan, 2011); Riggins R. Earl, Jr., Dark Symbols, Obscure Signs: God, Self, and Community in the Slave Mind (Knoxville, TN: University of Tennessee Press, 2003); John W. De Gruchy, Being Human: Confessions of a Christian Humanist (London: SCM Press, 2006); Spencer Wells, The Journey of Man: A Genetic Odyssey (Princeton, NJ: Princeton University Press, 2002); and Archie Smith, Jr., The Relational Self: Ethics \& Therapy from a Black Church Perspective (Nashville, TN: Abingdon Press, 1982). 


\section{Culture}

Indeed, culture encourages resurfacing of memory and enactment of memory. Culture is connected to memory. Such a broad definition can teach the educator how to peel back the layers in the dynamic of collective culture. ${ }^{4}$ Memory includes collective memory of family, neighbourhood, region, country, and/or hemisphere. One obvious memory is the theological which includes harmony and balance among different experiences between the penultimate and the ultimate. We humans are caught up in the penultimate, the next to the last things. Even as we resurface our memories, we are dealing with the penultimate. But what gives meaning to our human penultimate memories is the ultimate. Only God can provide the Ultimate. In other words, in our effort to go beyond the boundaries of penultimate, in our human past, we human beings confront an inability to understand all things outside of ourselves. Consequently, by looking at the limitations of our human history, we open ourselves up to a possibility of a larger narrative in our resurfacing of and enactment of memory. In other words, human existence contains a will to go beyond the limitations of its own past recollections. Yes, that which human being can touch, see, feel, taste, and smell points to culture. But, at the same time, a larger, overarching and invisible energy or Sacred Spirit [agitating the life of the cosmos, ecology, plants, animals, and the laws of nature] breathes life into the material sensory operations evident in all of creation. This energy is synonymous with the larger narrative. It is Sacred Spirit that gives meaning to the limited memories of our culture.

Moreover, remembering how the memories of our culture play themselves out differently for the different students in our classroom. For instance, a variety of international students originate from intergenerational,

4 I have an expanded investigation and definition of "culture" in my Being Human: Race, Culture and Religion (Minneapolis, MN; Fortress, 2005). Additional texts with further insights: Africa Information Service, ed. Return to the Source: Selected Speeches of Amilcar Cabral (New York: Monthly Review Press, 1973); Amilcar Cabral, Unity and Struggle: Speeches and Writings (New York: Monthly Review Press, 1979); David Morley and Kuan-Hsing Chen, eds., Stuart Hall: Critical Dialogues in Cultural Studies (New York: Routledge, 1996); Delwin Brtown, et al., Converging on Culture: Theologians in Dialogue with Cultural Analysis and Criticism (Oxford, England: Oxford University Press, 2001); and Dwight N. Hopkins and Sheila Greeve Davaney, eds., Changing Conversations: Cultural Analysis \& Religious Reflection (New York: Routledge, 1996). 
interconnected memories. For example, some students from around the world can literally trace blood ties for one thousand years. More specifically, one can find this manifestation in family written recordings passed down to subsequent offspring. ${ }^{5}$ On a more limited-time micro level, an individual can resurface the direct memory of his/her personal experiences from family and broader communal relations. In a classroom of global students, one can see personal historical memory beginning roughly between ages five and eight. However, if bad or good trauma impacts a child at a much younger age, that many-layered trauma, due to the severity of its indelible consequences, has the potential to brand the spirituality and physicality of the adult human in such a way that he/she can resurface memory from age two. To resurface culture points to the conscious dynamic of historical regurgitation of the intentional and unexpected dimensions of being human. Some memory we can control; others seem to control us.

But culture is more than resurfacing. It is enactment as well. Thus, it is the human agency and pioneering subjectivity of future practices derived from human being's visioning. In this sense, therefore, culture brings together the strands of resurfacing of the past with enacting practice in the present for realizing the new of the future. To a large degree, parts of culture as human resurfacing and enactment flow out of the flexible impact of nature, time, and space. Such three-dimensional realities present a context for the human being's culture. Culture resurfaces how being human crawls out of long historical memories. And culture is pregnant with the possibilities of human being's enactments into the future.

\section{Theological anthropology}

And so, classroom teaching has to take seriouslyhow culture encourages both resurfacing of memory and enactment of memory. Regarding theological anthropology, my teaching approach leans toward the following definition: "Theological" carries with it a connotation of some transcendence beyond one individual human being. "Theological" by definition lives an international resonance. It entails Greek words at its root - theos and

5 At least one East Asian student shared this insight and then produced his family's millennial documentation. African students have represented similar memory through orality. 
logos - showing Greek origins. Then Jewish Christians (Paul being part of this meaning expansion) adopted and thought together the Greek and the Jewish traditions of concepts and belief about Gods. "Theological" migrated from Northeast Africa or West Asia to Europe ${ }^{6}$ where "theological" (a Greek and Jewish fashioning) became absorbed in different, European tribal and city wisdoms. Now "theological" drifted into various streams of local humanistic and spiritual currents. As European missionaries spread an already multinational layered definition of "theological" to parts of the globe, "theological" recruited and mobilized and was recruited and mobilized by local primordial transcendent orientations toward the world. "Theological" is traditionally and historically multinational (and multicultural) and it forged further multinationalism when it went out to recruit others into its own meaning-making transcendence conclusions. Christianity already included different strands of cultures. Its missions went out and brought in even more cultures.

The anthropology aspect of theological anthropology connects anthropos with $\log o s$ and, likewise, embodies multinationalism along a similar traditional and historical path. Furthermore, if "theological" points to the transcendence beyond one individual human being, then anthropology describes the fact of human beings creating stories about transcendence beyond the individual self. Stories of intergenerational family journeys, specifically how they collectively came to terms with maintaining the relation between wealth (i.e., earth, air, and water) and family structures (i.e., the intra-duties of production and reproduction of the family), ${ }^{7}$ make

6 See Philip Jenkins, The Next Christendom: The Coming of Global Christianity: revised and expanded edition (Oxford, England: Oxford University Press, 2007); Adrian Hastings, ed., A World History of Christianity (Grand Rapids, Michigan: Eerdmans Publishing Company, 1999); Lamin Sanneh, Disciples of All Nations: Pillars of World Christianity (Oxford, England: Oxford University Press, 2008); Idem, Translating the Message: The Missionary Impact of Culture (Maryknoll, NY: Orbis Books, 1990); Laurenti Magesa, Anatomy of Inculturation: Transforming the Church in Africa (Maryknoll, NY: Orbis Books, 2004); Jose Miguez Bonino, ed., Faces of Jesus: Latin American Christologies (Maryknkoll, NY: Orbis Books, 1984); and Kwok Pui-lan, Postcolonial Imagination \& Feminist Theology (Louisville, Kentucky: Westminster John Knox Press, 2005).

$7 \quad$ Friedrich Engels, Origins of the Family, Private Property and the State (New York: Penguin Classics, 2010); David Parkin and Linda Stone, eds. Kinship and Family: An Anthropological Reader (Hoboken, New Jersey:Wiley-Blackwell, 2004); Allen Johnson and Timothy Earle, The Evolution of Human Societies: From Foraging Group to Agrarian State, Second Edition (Palo Alto, CA: Stanford University Press, 2000); David Carrasco, 
up the basis for narrative traditions about spiritualities, self-cultivation practices, and religions through times and spaces.

\section{Comparative method}

Moreover, a teaching practice that deals with the relations among cultures, international relations, transcendence beyond one person or people encourages students to identify their own realities by consistently and consciously utilizing a comparative method. For instance, whatever particular claim a student makes, he/she has to give his/her viewpoint in relation to a different culture in the class. And each student is asked to pursue this comparative method by examining the comparisons on different levels of being human - that is, on the family level, spirituality or religion level, indigenous tradition (space and time) level, and economic level. At the end of the class, each student is asked what "being human" means in his/her particular country after being in a classroom of different cultures.

Such a comparative approach applies directly to my own teaching definition of theological anthropology. In the classroom, for the purpose of teaching, I begin the conversational journey by saying that theological anthropology and being human are synonymous. Students from different nations are invited to challenge this stance from their own literary texts and common-sense wisdom experiences. As professor, I maintain my position that theological anthropology and being human are talking about the same thing. Students have to struggle for and defend whether they agree with my teaching position equating the two. To study being human in a multinational classroom calls on the professor and students to act out the definition of being human in the actual teaching situation. Restated, students and professor debate and defend their views of theological anthropology with compelling evidence in a public arena filled with the instructive practical examples of multi-cultures.

Religions of Mesoamerica: Cosmovision and Ceremonial Centers (Prospect Heights, IL: Waveland Press, 1998); Michael Loewe and Edward L. Shaughnessy, The Cambridge History of Ancient China: From the Origins of Civilization to 221 BC (Cambridge, England: Cambridge University Press, 1999); and Basil Davidson, African Civilization Revisited: From Antiquity to Modern Times (Trenton, New Jersey: Africa World Press, 2001). 


\section{Pedagogy's content}

Within the comparative transnational classroom, teaching consists of at least three things: conversation, ${ }^{8}$ questioning, ${ }^{9}$ and opening up traditions to new perspectives. ${ }^{10}$

\section{Conversation}

Lectures and assigned texts initiate and are the bases of the conversation. Through these two media, professors assume certain traditions are important for the conversation. These legacies - history of ideas, transcendent transferred human experiences - serve as launching pad and loose framework for the following conversations. Thus, on the one hand, conversation is not defined by the dogmatic display of the professor's ego. On the other, neither is it simply students telling their personal stories. It is, again, the conscious and meticulous assertion of certain crucial traditions relative to the class subject matter. In this regard, conversation hovers around and breathes energy into traditions and shows how these traditions are spiritual. These traditions are intellectual and practical legacies that give us rich and provocative insight for today. The lectures and assigned texts speak to this.

In global teaching, the professor's lectures need to be comparative. A deep grasp of his/her cultural foundation and some appreciation of

8 In his Dialogue with the Other: The Inter-Religious Dialogue (Louvain, Belgium: Peeters Press, 1990, p. xi), David Tracy writes: "Indeed, I believe we are fast approaching the day when it will not be possible to attempt a Christian systematic theology except in serious conversation with the other great ways."

9 David Tracy writes: "Conversation "is questioning itself. It is a willingness to follow the question wherever it may go." See his Plurality and Ambiguity: Hermeneutics, Religion, Hope (San Francisco: Harper \& Row Publishers, 1987, p. 18). Ukachukwu Chris Manus reminds us that all conversations and interpretations are particular. See his Intercultural Hermeneutics in Africa: Methods and Approaches (Nairobi, Kenya: ACTON Publishers, 2003). And Patricia Hill Collins further claims that voice in conversation is political. See her Fighting Words: Black Women and the Search For Justice (Minneapolis, MN: University of Minnesota Press, 1998).

10 For instances of questioning traditions, see Michel Foucault, Lectures on the Will to Know: (Lectures at the College de France 1970-1971 and Oedipal Knowledge) (New York: Palgrave Macmillan, 2013); Idem, The Archaeology of Knowledge (New York: Vintage, 1982); and James H. Cone, Black Theology and Black Power (Maryknoll, N.Y.: Orbis Books, 1997). Also see my "Postmodernism, Black Theology of Liberation, and the U.S.A.: Michel Foucault and James H. Cone," Journal of Hispanic/Latino Theology, May 1996, vol. 3 no. 4 . 
other cultural perspectives enable the lectures to have some sense of comparative engagement. To have a life-giving enriched and truly enjoyable international conversation within the teaching moment and process calls on the professor to be knowledgeable of and an authority on his/her own cultural gifts to the present. International teaching, by definition, does not presuppose, at the beginning, that students grasp all nuance cultured conversations different from their family of origins. At the end of the class conversational journey, we can expect this way of being in the world. The professor, to produce effective lectures welcoming the challenges from global conversation partners (which, indeed, signify the roles of students from different countries), must point out openly the historical examples of the cultural leanings he/she brings to the table. Only by being self-aware of one's own cultural legacy can the lectures provide a basis for comparative conversation. Thus, the professor's lectures act as one plumb line to encourage critical discovery and crucial disagreement. This models for the students how to offer their own family of origin insights. It is a gracious invitation for us to talk.

In addition to self-asserted culture, the professor's presentations need to include comparative dialogue. For example, it enhances the lectures if the professor can compare his/her own culture with the cultural tradition of another people. One need not be an absolute authority on another culture to facilitate the give-and-take of classroom energy. However, it does help immensely to comprehend dimensions of one or two diverse cultural legacies as comparative paradigms.

Accompanying the lectures, assigned books serve as a second plumb line nurturing and nudging the global comparative conversation in the class. If we announce the necessity of worldwide conversation about human culture, the assigned bibliography can move us toward succeeding in that announcement. In actuality, required readings serve as one easy way of honouring the teaching of comparative transnational experiences. Specifically, as the larger subject matter unfolds within its constituent parts, each subset of the syllabus indicates perspectives from books emerging from different regions of the world (specifically, Africa, Asia, the Caribbean, Europe [inclusive of all cultures in Europe], South America, North America [inclusive of all North American cultures], and the Pacific Islands). The comparative bibliography, if properly handled, can avoid 
missionary teaching; that is to say, the West (i.e., the United States and western Europe) sees other world peoples on the syllabus in order to, ultimately, suck them into a western European way of being and thinking. ${ }^{11}$

Assigned and recommended books, truly regionally representative, moreover, can avoid the tendency and the pressure for the (in particular, the USA and western European) professor to self-proclaim authority over and authenticity about the Rest - the non-West. If patiently done well, the syllabus bibliography can serve as preparation, as tools, as living testimony to collaborative teaching framed within the overall syllabus, inclusive of assigned readings, and energized by the professor's lectures. In addition, the assigned and recommended readings on the syllabus need to facilitate comparative and interdisciplinary approaches to teaching. Because teaching being human globally, by definition, denotes multinational investigation of the subject matter, the syllabus, then, has to reveal texts from different countries. But just as important is an interdisciplinary representation of texts in the syllabus. Theologically Christian doctrines of being human will be present. However, one must be intentional in one's definition of being human. A global pedagogy, even if biased toward Christianity, needs to realize that Christians are not the majority of the 7.7 billion people of the world population. Thus, being human in the world presents multiple ways of being human, inclusive of Christian dogma as discipline as well as a variety of human theories as disciplines. We realize therefore in teaching method that human being denotes world diversity across spiritualities, self-cultivation practices, and religions.

We recognize, moreover in teaching method (that is to say in lectures and syllabi), an understanding of human being fluctuates and differentiates even among self-professing Christian adherents as Christianity is believed and practiced in different nations located in the classroom. For most western professors, the idea that there is one Christianity in the world underscores, at least, two possible short-sighted perspectives. Either that American or western European professor has never had classes packed with students from the majority of the world or he or she, as an academic seeking new

11 See Eduardo Mendieta, "Imperial Somatics and Genealogies of Religion: How We Never Became Secular," in Postcolonial Philosophy of Religion, ed., Purushottama Bilimoria and Andrew B. Irvine (Dordrecht, Netherlands: Springer, 2009), 235-50. 
knowledge, has never travelled around the world. In short, the notion of teaching the one Christian thought, belief, or practice regarding being human is blurrier than crystal clear.

And so, one realizes, in teaching conversations, that Christian expressions of being human globally include mixed expressions of indigeneity and missionized Christianity. ${ }^{12}$ This should not be a startling fact. Indeed, even within the USA, the different Christianities manifest a mixture between missionized Christianity, originally from western Europe, and the indigenous spiritualities and cultures of those who were missionized in the USA. Similarly, as Christianity spread from the early church to different parts of Europe, this missionary Christianity, itself, took on and incorporated local indigenous European cultures into the Christian missionary arrivals-- witness a pagan Christmas tree associated with Jesus' birth and a pagan bunny rabbit mapped onto Jesus' resurrection. ${ }^{13}$

The New Testament Paul serves as exhibit A. The Christianity that Paul mixes together is his creation of at least two ingredients. The first part juxtaposes his interpretation of Jesus' stories with Greek culture, which is the second aspect. The result of this two-dimensional recipe is Paul's faith in and experience of Christianity. In a similar way, witness the prologue of John 1:1: "In the beginning was the word [Christian culture]" who is the logos [Greek culture]. For Paul the word is Jesus, the highest principle of the reality in the world he knew around the Mediterranean Sea. In order to convert or recruit part of the Greek world, he had to find the Greek idea for the highest principle in Greek culture. For the Greeks, the highest principle was "logos": Reason. So, Paul, like John, equated - intentionally syncretized - Jesus, a Jew, with Reason from Greek culture. Paul's Christianity is the ultimate syncretism for people who call themselves Christian. Paul is syncretistic in his interpretation of Jesus' narratives and compromising in his inclusion of non-Christian sources.

12 See Lydia Johnson and Joan Alleliua Filemoni-Tofalono, eds., Weavings: Women Doing Theology in Oceania (Suva, Fiji: Weavers, South Pacific Association of Theological Schools, 2003).

13 See Mary N. Getui, Tinyiko Maluleke, and Justin Ukpong, eds., Interpreting the New Testament (Nairobi, Kenya: ACTON Publishers, 2001). 
In other words, even before Europe sent missionaries to other parts of the world to recruit other people, European Christianities were themselves clear expressions of different mixtures that were called orthodoxy. And so, when teaching being human internationally with a heavy or implied Christian intent or affect, the teaching effectiveness increases when the professor foregrounds the reality of different (religious, spiritual, and selfcultivation) means of being human. In a word, the professor should state up front that Christianity, itself, is a mixture of ways of being in the world; and in the world there are many, many ways of being human. This theoretical analysis, at the beginning of the class, can free up the critical thinking deep within the students' brains. If handled properly, students can claim the many voices of their local religious, spiritual, and self-cultivation stories which come from their own familial and communal traditions. And they can do this without pausing to self-edit themselves in class for fear of being positively orthodox or negatively syncretic on the being human question.

\section{Questioning}

Indeed, in addition to a complex dimensional conversation, global classroom teaching entails perpetual and unencumbered questioning relative to lectures, assigned texts, and scholarly concepts raised during discussion periods. Though we have to be sensitive to avoid personal ad hominem attacks (especially with students from around the world where language nuance, body rhythm, and ritual themselves can define what it means to be human), good teaching fosters, at times, very intense pointed questioning. Fundamentally, questioning realizes at least three purposes: (1) to teach students (i.e. give them permission) to not accept anything as given, (2) to challenge students to defend the fundamentals and presuppositions of their arguments, and (3) to remind both questioner/challenger and responder/ defender to always make clear the local cultural context of the challenge and the defence. Questioning surfaces from and situates itself in the local cultural realities of students debating their perspectives among the whole class as the professor makes sure to broaden the open-ended process of questioning.

Fostering a sense of the communal value of not accepting anything "as is" requires patience on the part of the professor due to the transnational makeup of the classroom. Naturally and understandably so, students from diverse 
nations assume that each student participant acts as a unique authority and lives his/her own knowledge and location of wisdom as an expert. As a corollary, it might, at first, appear rude to not embrace the opinions of classroom colleagues from another international region. However, the professor encourages probing beyond the given as profound compassion for the ideas of different global students. The professor constructs a teaching and theological atmosphere where students can deconstruct their own initial shields of false politeness. Students eventually learn to love the wisdom, theories, and thought systems of others to such a degree that they are willing to take them so seriously and listen so carefully that they will not automatically agree with all initial arguments. All nations are made of the same brilliant and fallible human beings. And seeing the human being in each classroom neighbour suggests a visual perspective, valuing recognition of the weight of another human being's verbal contribution to dialogue and debate. To affirm and to clarify is a form of compassion for the one sitting next to us.

Such compassion and worldview go together and connect with the challenge of raising questions about presuppositions and fundamentals. To show sympathy for and recognition of the other human's individual risk to think aloud in a class room as part of collective processing demands a teaching atmosphere of compassion but also disagreement with fundamentals and presuppositions all the way around. What are the assumed commonsense wisdoms and taken-for-granted reflexes breathed like natural air in the home countries of the students? Each student has to learn that sources of knowledge emerge from materialities embedded deep within each nation's personality. Fruitful scholarly class adventures begin when student speakers confront one another's fundamentals (that is to say, the material basis of each other's ideas). For instance, a student speaker might assume an immense amount of human diversity and opposite thinking and practice when he/she is arguing among other citizens at home in his/her own country. However, in a transnational classroom, other international students can see how what might appear as opposite views of citizens in one country are, in fact, a manifestation of what truly defines the national common character of all the citizens in that same country.

Citizens of the United States, as an example, pride themselves for fighting over racial uniqueness and asymmetrical power relations domestically. 
But in a class of nations, even black American students can be very, very American, especially in the revelation of that religious-like American presupposition of the fundamental American God of individual rights. It can be a sacred preoccupation particularly when U.S. citizens become insensitive to hosts countries granting these Americans, of all colours, the kind privilege of a visa for entrance. At home, many Americans dispute race and different power positioning; yet, all Americans tend to fight for their individual rights even though a host country has done them a favour by granting them a visa, which calls for Americans to abide by the local laws and customs of the host country. And so, in this classroom of multinational comparison, American students can discover the basic value of what it means to be a human being from the United States when probed by other foreign students' foundational insights. In particular, other global classroom neighbours can aid the clarification of an American being human by assisting the students from the United States in distinguishing between a harmful way of thought and life defined as individual rights from another American gift designated as individuality - the inherent sacredness of individuality serving the collective.

In a word, questioning presuppositions inevitably shines the teaching spot light on the cultural contexts of both the student challenger and the student defender of arguments. Students in different nations might relish a certain type of claim about wealth, structure, time, body, space, or family duties. Culture determines decisively these ideas. Take Christianity. In a multinational classroom, teaching, even teaching about so-called universal Christian Dogmatics and ritual, depends on the culture surrounding dogma and doing. If students could learn about each other's supposedly universal Christian talk and walk by visiting each other's nations, they would, for the most part, witness unique human practices from long cultural traditions determining the acceptance and practice of Christian orthodoxy and orthopractice. Human culture, therefore, can help give energy to thought, duty, and feeling. It classifies and colours the Christian deity. And it manages and filters being human. Having looked at conversation and questioning, let's turn to traditions. 


\section{Traditions}

Both conversation and questioning inspire the multinational classroom to a teaching of opening up traditions to new perspectives. ${ }^{14}$ New knowledge for the world's common good can burst forth from questioning, in a global comparative sense, legacies handed down through centuries and millennia. It is this comparative inter-nation dialogue that facilitates a student who is foreign to another student's reality to see something new in an ancient memory. On the one hand, a student upholds a sense of insight of his/her own tradition. On the other hand, the student foreign to this intergenerational path can bring fresh eyes to bear. Hopefully mutual questions about divergent histories will lead each student to appreciate more profoundly aspects of their own traditions. It can, likewise, instruct each student to walk some critical distance away from less meaningful moments in the history of ideas of his/her tradition.

For instance, various countries accent the family structure and familial duties as a prime criterion for being a civilized human gathering. In contrast, other nations accentuate each family member's highest allegiance to his/ her own individual voice to pursue his/her own individual preconceptions of being human. And so family means, in one instance, subordinating the individual to the family. In the other, it means the individual is above the family. In a similar fashion, different nations concoct notions of wealth ownership; some privilege private accumulation; others prioritize collective participation. Both perspectives flow from and are implicated in persisting deep forces of habit where human cultures create the context of human being. Adherents of both perspectives think something good lives within his/her own country's tradition. Classroom teaching then instructs

14 Western European creation of new knowledge is emblematic of how one episteme gave way to another; that is to say, the prism of thought of feudalism dialectically sprouting into new bodies of knowledge under capitalism. See Marimba Ani Yurugu: An AfricanCentred Critique of European Cultural Thought and Behaviour (Trenton, New Jersey: Africa World Press, Inc., 1994); and Ian F. McNeely and Lisa Wolverton, Reinventing Knowledge: From Alexandria to the Internet (New York: W.W. Norton \& Company, 2009). To entertain one's curiosity about the formation of knowledge, in a contrasting approach, see Christian Jennings and Toyin Falola, ed., Africanizing Knowledge: African Studies Across the Disciplines (Piscataway, N.J.: Transactions Publishers, 2002); and Colina Mason and Felicity Rawlings-Sanaei, eds., Academic Migration, Discipline Knowledge and Pedagogical Practice: Voices from the Asia-Pacific (Berlin, Germany: Springer, 2013) . 
these students to be gracious enough to accept the warm invitation from other foreign students to compare and contrast, thereby discovering new interpretations out of the past. Basically, opening up ancient periods, from teaching students to speak about and hear each other's traditions, emerges into new collective, life-enhancing ways of being in the world.

Moreover, opening up traditions can create the potential of world peace and material and spiritual collaboration. As foreign students talk about (on a conscious level) the long histories of divergent traditions, understanding can follow as an ultimate teaching revelation. In my classroom experiment referenced at the start of this chapter, a recurring question pressed for clarity about why so much of the West clings to Christianity. Actually, Christianity served at points, and especially during the Middle Ages, as glue and transmission of Western civilization when forms of state power and attendant structures weakened. And so, western Christian thinkers have been one medium of preserving western culture. ${ }^{15}$ In addition, many people of colour in the United States re-appropriated certain styles of missionary introductions of Christianity in their communities to create their own syncretized Christianity, so that these communities of colour then could make meaning out of materiality. And they could then selfapply their new forged Christianity as a balm for psychological wholeness. ${ }^{16}$ Thus, the passed-down stories of Christianity in the West enabled various sectors of the West to maintain civilization and life in the face of death. Such traditions helped both the mainstream dominant Christianity and the Christianity that was appropriated by people of colour.

Likewise, the students' experiences of digging into the taken-for-granted inheritance in other global regions sitting in the classroom can compare and

15 See the work of my University of Chicago Divinity School colleague: Willemien Otten, "Middeleeuwen tot en met Reformatie. (Ont)spanning tussen geloof en rede," in Perspectief op leren. Verkenningen naar onderwijs en leren vanuit de christelijke traditie, eds. A. de Mynck and B. Kalkman (Gouda: Driestar Educatief, 2005), 57-69. Other helpful texts: Joseph H. Lynch, The Medieval Church. A Brief History (London/New York: Longman, 1992) and Catherine M. Chin, “The Grammarian’s Spoils: De doctrina christiana and the Contexts of Literary Education", in Augustine and the Disciplines. From Cassiciacum to Confessions, eds. Karla Pollmann and Mark Vessey (Oxford: Oxford University Press, 2005), pp. 167-83.

16 Dwight N. Hopkins, Down, Up \& Over: Slave Religion and Black Theology (Minneapolis, MN: Fortress Press, 1999). 
contrast their different historical journeys. These historical traditions lead directly to who the students are and their family structures and ownership of wealth, two components, among others, of being human in examples of one-to-one relations and in the larger political economy dimension. The increased understanding of where neighbours come from hopefully can engender peace and prosperity for all countries. This teaching can have a profound spiritual value. Legacy means the transcendent transference of things greater than the individual self; thus, it is spiritual because it lives on inter-generationally for years into the future. Perhaps this long view of history relative to family and wealth constitutes a major potential for mutual understanding among the multination classroom of foreign neighbours. I would argue family-wealth perspectives undergird different local spiritualities, self-cultivation practices, and religions.

For example, even in the Christian narrative, a disproportionate number of Jesus' stories (in the memory of Matthew, Mark, Luke, and John) refer to wealth and, one could add, to the idea of the family's relation or lack of relation to wealth. ${ }^{17}$ Relatedly, from the Christian appropriation of the Hebrew legacy, the Hebrew Bible unfolds as Yahweh promises, moulds, and struggles with family relations of the ancient Hebrew people (from Abraham to the 12 tribes) while they deliberate over wealth accumulation. Yahweh promises Abraham an abundant family offspring gifted with prosperity. Later Yahweh removes the ancient Jewish families as material wealth from Egyptian material slavery. Then, in the book of Numbers, Yahweh promises the accumulated remnant of families posed at the edge of the wilderness a land of wealth, flowing with material milk and honey. By unwrapping

17 Liberation theologies from Africa to Asia write on these notions of Jesus, wealth, and social connections. For Latin America's form of liberation theology and these ideas, see Ignacio Ellacuria and Jon Sobrino, eds. Mysterium Liberationis: Fundamental Concepts of Liberation Theology (Maryknoll, N.Y.: Orbis Books, 1993); especially refer to Gustavo Gutierrez' chapter "Transcendence and Historical Liberation: Option for the Poor." Also check out J. B. Banawiratma and J. Miller, Contextual Social Theology: An Indonesian Model (Quezon, Philippines: East Asian Pastoral Institute) (a book of the East Asian Pastoral Review 36 [1999], nos. 1 and 2). And see my Heart and Head: Black Theology, Past, Present and Future (New York: Palgrave, 2002), especially "The Preferential Option for the Poor and the Oppressed" and "A New Commonwealth" chapters. From South Africa, review Itumeleng J. Mosala, Biblical Hermeneutics and Black Theology in South Africa (Grand Rapids: Eerdmans, 1989). And from Cameroon, Jean-Marc Ela writes My Faith as an African (Maryknoll, N.Y.: Orbis 1989). 
this memory of human imaginations, one can better appreciate why today's adherents of these past creative narratives do what they do now.

So too, by divulging each foreign student's passed-down written and oral talk intergenerationally, other students have the possibility of grasping why students (representative of their diverse countries) and their respective nations think, believe, and do "as they are" - that is to say, the intertwined necessity of legacy and being human. Opening up traditions to new perspectives can circulate exchanges of knowledge toward understanding, toward friendship, toward peace.

\section{Music and language in pedagogy of being human}

In addition to the formal lectures, syllabi, and crucial debate among students, discussions about music and language among foreign neighbours in the classroom present an invigorating challenge of eventual mutual trust and understanding. Furthermore, oftentimes music and language concerns are linked to ultimate-meaning matters such as spiritualities, self-cultivation practices, and religions.

Teaching the community-building effects of music offers several approaches. A professor can decide on or solicit one song known across the world and have the students explain the substance and impact of the chosen piece in their local context. Here too music differentiates between explicit religious lyrics and "so-called" secular tunes, though in the porous and malleable walls of division there hardly stands an impenetrable partition. In either case, a common tune provides the basis for exploring being human. With the shared song, each country representative can disclose what the lyrics mean in his/her interpretive perspective. Specifically, each elaborates on the implications for being human. On the one hand, everyone is familiar with and knows the words to one global song. Hence, the class has a provision for collective knowledge. On the other, the sparkles and fusion of new knowledge emerge in the mix of multiple, oftentimes competing, claims to significance from particularity. Even with a given transnational song, each country not only nuances its implications for being human differently. At the same time, each context brands the global song with each local cultural particularity when local artists sing the song with their own cultural presuppositions. The being human of the local morphs the globalness of the song into a hybrid local-global humanity. What meaning 
for human being is found in the transnational and the particularity when a Korean student from a Confucian background enjoys black American soul or gangster rap music? How do the Negro Spirituals facilitate the new understanding of being human when embraced and sung by citizens of the former communist Union of Soviet Socialist Republics? ${ }^{18}$

Additional collaborative pedagogical awareness appears when students present songs from their native nations. The sheer novelty and strangeness of each song to other classroom neighbours can yield a rewarding result. The student describing his/her artistic piece usually resorts to the human or family or spiritual heritage undergirding the song. The student often describes the ritual setting in which the song is sung or even performed. This varies from the mundane (i.e., song for walking) to the intimacies of nurturing (i.e., song for a mother to her baby) to the more microregularized event (i.e., song for family singing traditions) to the obligatory (i.e., song for the dead ancestors) to the more advanced complexity (i.e., song for national festivals). To share with depth, each student will respond further to the question: What is at stake in the theological anthropology of the song in the present? How have the orthodoxy (i.e., correct beliefs) and orthopraxis (i.e., correct practices) of the song mutated and how has the mutation (comprised both of things held on to and things newly introduced) impacted previous and emerging constructions of being human? At some point the student attends to both the material tangible and the spiritual transcendent.

Moreover, the very unfamiliarity of the tune allows for other foreign students to raise questions for clarification that the student describing his/ her song had never thought to think about due to the force of habit brought on by routine of the familiar. The growing collective energy in the room snakes throughout the class. Some students try to situate the song within their own local musicology. Others try to map, and thus control, the song by framing it within superficial stereotypes of the nation from which the song

18 In my talks on being human in South Korea and Cuba, I introduced the African American religious song "This Little Light of Mine". To my amazement and delight both audiences immediately joined in the English lyrics and sang with much gusto, though they added their own flavour which would have been fascinating to black Americans but somewhat culturally particularized by the South Korean and Cuban realities. Similarly, the African American freedom song "We Shall Overcome" has been sung all over the world by people bearing the brunt of asymmetrical power relations. And, furthermore, perhaps one of the most global classics is Bob Marley's reggae music. 
hailed. Whatever the case, students can begin to ask questions such as what type of people would produce such a song; what existential and theoretical purpose does it serve; how does it relate to building communities; what spiritual endurance does it portend? And what does all of this collective cacophony and communal consensus say about my own limited notion of being human or theological anthropology in a world of foreign neighbours?

Like music, language can open up new vistas for teaching being human in a multicultural and transnational classroom situation. The professor can commence the process by choosing one word, in this case, a word in English, since foreign students have often assimilated English in order to operate at a worldwide academic level. ${ }^{19}$ Students are challenged by the professor to contemplate both the meaning of the word for them and their particular accented way of pronouncing the English word. For instance, in U.S. English, most give a hard accent on the last letter or syllable in a word. In Putonghua (i.e., Chinese Mandarin), one can pronounce lightly the ending of a phrase or a word. ${ }^{20}$ One could speculate that two distinct students articulate the same English word differently because the diverse method of pronouncing the common term signifies two unique ways of being human on the spiritual, intergenerational, transcendent plane. Putonghua is linked to a long Confucian and Taoist legacy of what constitutes a good person. The Confucius person is modest and learned. The Taoist master might appear as a beggar or homeless individual. A distinction divides and unites appearance and essence, surface and depth. A crouching tiger and hidden dragon warn us that behind the outward ordinary shines the hidden heroic.

In usual contrast, the USA human being can at first seem pushy, loud, aggressive, and demanding in a global conversation. Both law and faith undergird this apparent individualism. The very first amendment of the U.S. Constitution grants the right to shout out each person's personal voice. And the second amendment gives each citizen the right to kill someone who infringes on this individual speech. One might add to the U.S. personality a proclivity for Christianity, a major U.S. religion inextricably woven into

19 The United Kingdom and USA universities remain influential on the world stage. Harvard University's endowment is about $\$ 33$ billion.

20 See Jia Xue Rui, A Comparative Study of Chinese and America Communication Styles (Harbin, Heilongjiang Province, China: Harbin Institute of Technology Press, 2008). 
the politics and economics of the U.S. society. Linked to the law, one, in addition, feels one has to boldly proclaim the Christian Word and then aggressively travel the world recruiting people based on this Word. ${ }^{21}$

Akin to the pedagogical exercise of music, the professor can move from articulating and interpreting a commonly known English word to positing an idea and having each foreign student speak the term in his/her own native tongue. For example, what does the word "greetings" denote for being human in disparate global classroom tongues? In U.S. English, one usually states, "How are you?" or "Good to meet you." Yet, in certain African countries, citizens recognize one another in a communal fashion. Instead of "How are you", they embrace each other with the sayings "I see your family" or "Health to your family." The usual U.S. greeting speaks to the spiritual definition of being human. An individual, especially the Christian American person, stands before his/her maker alone, without one's father or mother. And each singular individual is accountable to this deity based on the individual's faith and witness. Certain African paradigms postulate a spirituality of collectivity with a family recognition inclusive of the unborn, dead family ancestors, and living family kin. To be human is to embody and recognize family ancestors and living family relations in each person. Or rather, one sees the individual not as an individual acting on his/her own. The communal family lives in that one individual. In actuality, a person is not one individual but someone part of a collective chain, a collective family, spiritual personality.

Here we selected music and language. For pedagogical purposes, the professor could choose food, smells, architecture, the purpose of furniture, or a broad array of the quotidian and the extraordinary. For indeed, the being human from all countries hold this in common. All people are people who soar high and low in living out their transcendent and intergenerational connections to meaning-making in communities.

\section{Conclusion}

We began this investigation with a plumb line marker: How does an educator teach the idea of being human among different nations situated in

21 Check out Matthew 28:16-20 and Mark 6:7-13 on what people think Jesus said about going to foreign neighbours. 
the same classroom? Theoretical curiosity can, rightfully so, prompt such a fundamental direction. Yet, such a theoretical study, indeed any such study, will be immensely elevated when grounded in the realities of the twentyfirst-century practical implications of technological, microwave-like instantaneity. Specifically, contemporary invisible, communication media allow a human being to never sleep and to be present in any place in the world without physically being there. Today is what many fantasized about with Dick Tracy ${ }^{22}$ and his "magical" wrist watch, which was a combination of television and telephone and beyond. In a sense now the world is Dick Tracy.

Specifically, my class of students from China, Korea, Thailand, Pakistan, Ghana, and the United States, cited at the top of this essay, could have participated in my global pedagogy simultaneously on WeChat, skype or ooVoo. With coordination of time differentials among the various global regions present, we would all have been present in the "same" classroom at the same time without being present together physically at the same time. This is a form of transcendence of time and space. The materiality of accumulated human scientific risk taking, thinking differently, and the replication of experimentation in information technology, results in the nature of human being transcending the physicality of one's own individual self, transcending the exact limitations of the tangible and touchable place of the one individual.

In that expansive growth, some might cross-pollinate philosophies of being human or theological anthropology in relation to Christianity and the prohibitions of religions. Others might express a taste for the more freewheeling open-endedness of spiritualities. Still others might sample self-cultivation practices from thousands of years. Whatever the gardening process, we might all agree that the pedagogy of being human will probably sprout the most rewarding intellectual and existential buds of hope in a global and transnational horticulture of cultural plurality. And that ripe pedagogy could be one healthy fruit for world peace and friendship.

22 A comic strip character who first appeared in 1931 in the Detroit Mirror, Tracy was a smart futuristic detective. Actually, Samsung has, indeed, produced the first commercial wrist watch (the Samsung Galaxy Gear) that is basically the beginnings of a smart phone. 